In the case of the copper-tin series of alloys they find that, according to the temperature and constitution of the liquid, crystals belonging to no less than six different types may separate, numely :$a$, a solid solution of $\mathrm{Cu}$ with less than 9 per cent. of $\mathrm{Sn}$.

$\beta$, a solid solution of $\mathrm{Cu}$ with less than 27 per cent. of Sn. $\gamma$, of which the constitution is not known.

$\delta$, which probably has the composition $\mathrm{Cu}_{4} \mathrm{Sn}$. $\eta$, which probably bas the composition $\mathrm{Cu}_{3} \mathrm{Sn}$.

$\mathrm{H}$, which probably has the composition $\mathrm{Cu} \mathrm{Sn}$.

Both $\beta$ and $\gamma$ are unstable at ordinary temperatures. The compound $\delta$ crystallises out of $\beta$ or $\gamma$ while they are already in the solid state, when the temperature falls sufficiently.

A glance through the 101 photographs of chilled and etched ingots which accompany Heycock and Neville's paper on this series of alloys shows how impossible it would be from the final composition of the solid alloy to ascertain the various stages through which it has passed during cooling; as the authors remark, it is of the nature of a palimpsest. For example, the alloy, containing 14 atoms of tin to 86 of copper, consists at $800^{\circ}$ of a crystals in a ground-mass which probably contains $\beta$; it solidifies at about $775^{\circ}$; at $675^{\circ}$ there are only $\beta$ crystals; at $600^{\circ}$ there are $a$ and $\beta$ crystals, but here $a$ has crystallised out of $\beta$ after it became solid; at $530^{\circ}$ there is a much larger proportion of $a$; at $470^{\circ}$ there are $a$ crystals immersed in a mixture of $a$ and $\delta$ into which the residual $\beta$ has broken up on cooling.

If the course of events is so complex in an alloy of only two metals, how much more difficult must it be to decipher in the case of a mass of complicated silicates which are even more prone to form isomorphous mixtures, such as we have in a solid rock, not to mention the additional presence of aluminates, oxides, and sulphides. And yet geologists are accustomed to speculate freely about the crystallisation of rock constitnents from the magma without taking account of anything save the final stage.

I cannot help thinking that the experimental method of Heycock and Neville will have to be applied to the study of slags and fused silicates if we are to trace successfully the evolution of rock species. The value of their work to geologists is not only that the results are skilfully interpreted by the light of modern physical chemistry, but primarily that it is experimental work upon actual crystallising materials.

(To be concluded in our next number.)

\title{
COREESPOINDEIVOE.
}

THE CHALK BLUFFS AT TRIMINGHAM.

Str,-Students of East Anglian geology will read with some surprise, in the concluding paragraph of the paper by Professor Bonney and Mr. Hill on the Trimingham Chalk Bluffs, that a bypothetical interpretation of these masses was out of place in a Survey memoir. Surely in a work dealing with this district some attempt 
was demanded to account for phenomena which " have for many years attracted the attention of geologists" and now, even of the above-named authors themselves, albeit if with the knowledge then (1882) available an exact explanation was not possible.

Nor can it be said that Professor Bonney and Mr. Hill by their communication have advanced matters much, for unfortunately they appear to have left ont of sight two rather important items, viz., the fossil contents of the beds and the literature on the subject since 1882 .

Long familiarity with rocks which can only be studied stratigraphically and by aid of the microscope and field-glass may, perhaps, have led them to overlook the palæontological aspect of the Trimingham chalk masses. Professor Bonney, it is true, noticed the conspicuous Belemnite occurring throughout, but is not aware that it is of less importance as a zonal guide than the concomitant Ostrea, which does not occur throughout.

To thoroughly investigate the fossil fauna of a bed in cases such as the present one is not possible, however, to the casual visitant: it can only be done with long and patient research by one on the spot.

Fortunately the Trimingham chalk masses have had their historian in Mr. R. M. Brydone, who, with a care and patience that cannot be too highly commended, made a thorough examination of them, collected and worked out their fossils, and in 1900 published a pamphlet entitled "The Stratigraphy and Fauna of the Trimingham Chalk." In this he showed that the uppermost portions of the masses are the sole remaining vestiges in England of the Maestrichtian beds of the Chalk. He further discussed Mr. Clement Reid's theory, which in the light of these later researches he showed to be untenable and suggested that these masses were really buried seastacks. This view is supported by the Mundesley boring. Whether these pinnacles have remained upright, or have been crushed, crumpled, and overturned, is of little moment, but it is important to note that the strata in them are of the same age as the beds capping the mucronata chalk, that are exposed in the beach at extreme low water.

That these masses are part and parcel of the main Chalk strata that lie at no great depth under the beach at this spot, I was enabled to see in the Autumn of 1901 after a storm that had cleared away the beach for some distance round their base. The bands of flint were distinctly traceable down into and right across the exposed surface. The sketch and notes I made at the time were passed on to Dr. Rowe and Mr. Sherborn against the time when they come to deal with the Norfolk district.

B. B. WOODWARD.

4, Lonafield Road, Ealing, W.

[We have received several other letters on this subject, all embodying the same points of eriticism.-EDit. GroL. MAG.]

\section{THE RAISED BEACHES OF DEVONSHIRE AND OF THE SOUTH OF IRELAND.}

Sir,-I much regret to find that I have both misunderstood and misinterpreted Mr. Muff's ice-scored beach-platform in the South of Ireland.

Ever since Godwin-Austen in 1851 attacked the problem of the 